\title{
The "question" of American brigs seized by Murat for Napoleon order in Naples between 1809 and $1812^{1}$
}

\author{
Franca Pirolo $^{2}$ \& Maria Sirago ${ }^{3}$
}

\begin{abstract}
During the reign of Charles of Bourbon, the reorganization of a strong merchant navy was actively encouraged. These first attempts were followed by more frequent voyages to the Americas when strong merchant vessels were built in Sorrento. Then, at the end of the 18th century, after the American Declaration of Independence, first diplomatic relations were established between the Bourbon kingdom of the Two Sicilies and the United States, which intensified during the 19th century. After Napoleon's rise to power, the Italian Peninsula was invaded by the French in 1799. The Bourbons fled to the island of Sicily. Under Napoleon the Kingdom of Naples was ruled first by Napoleon's brother Joseph and then by Napoleon' brother- in- law Joachim Murat.

Murat decided to expand the arsenal of Castellammare and ordered to build three docks to make three vessels simultaneously (following a plan that was carried out later, in the 1820s, under the Bourbon rule). However, the recession caused by the English Continental Blockade (November $21^{\text {st }}$, 1806) hindered trade with the Baltic Sea, the Black Sea, and the Americas. The embargo was effective intermittently for about half the time and it ended on 11th April 1814, after Napoleon's first abdication.

The controversy arose in the years 1809-1812 when Murat, with Napoleon's approval, decreed that American ships that ventured out into the bay of Naples could be seized and confiscated: about 50 vessels were sold with their cargoes or added to the Royal fleet. In 1825 the issue of the seizure was reopened after the accession to the throne of Francis $1^{\circ}$, king of Naples, and the election of John Quincy Adams as President of the United States. In May 12, 1825 James Appleton became a «Special Agent of the United States in Naples» to settle the claim against Neapolitan Government. At the same time, count Ferdinando Lucchesi Palli di Campofranco was appointed consul in Washington by the King. In 1826, while talks over seized US ships and cargoes were still underway in Naples, and many merchants were sending reports claiming for damages, Edward Everett published a remark called «Claims of Citizens of the United States of America» complaining against Naples, Holland and France for the spoliations committed on US commerce during the Napoleonic wars. In 1831 President Jackson sent John Nelson, from Maryland, to Naples with explicit orders to settle the dispute. A definitive agreement was reached in October 1832, when Nelson returned to the United States with the text of the first convention between the United States and the Kingdom of the Two Sicilies. The king had to pay 2.155.000 Neapolitan ducats including indemnity for the destruction of vessels and cargoes. The sum of 7.685 ducats, subtracted from the total amount, was used to reimburse the United States Government for the costs of taking American seamen back from Naples in 1810. The sum was paid in ten years up to 1842.
\end{abstract}

Keywords: United States of America, Naples; merchant navy; trade.

\section{Introduction}

The economic, political and social situation of southern Italy radically changed since the arrival of the Bourbons in 1734. The ministers serving young king Charles soon spread European mercantilism in the Kingdom. Plans were made to restore the most important ports and revive trade. Since the early 1740s, military engineer Giovanni Bompiede carried out the restoration of the most important ports in the kingdom: Naples, Castellammare, Brindisi, Bari, Barletta, Trani, Crotone, and, in Sicily, Messina and Palermo. In the same period the reorganization of a strong merchant navy was actively encouraged because the merchant fleet, mainly assembled in the shipyards of Piano and Meta, near Sorrento, and on the island of Procida, was formed by small units which could not cover a very long distance. At the time, many exemptions from customs duty were granted, and it was established that the foremast fighting tops of some big vessels, used for long-distance voyages, should be equipped with guns. Some vessels, called "polacche" (polaccas) or "pinchi" (pinks) were built and used on the new trade routes.

\footnotetext{
${ }^{1}$ The Authors: F. Pirolo $\S \S 1,2$, M. Sirago $\S ~ 3,4$.

${ }^{2}$ Researcher in Economic History, Department of Economics and Business, University of Catania (Italy).

${ }^{3}$ Member of Maritime History Laboratory (Navb), Genova (Italy). 
Therefore, during the Seven Years' war (1756 - 1763), Gaspare Marchetti, a shipowner living in London, created a trading company for his maritime commerce in the Ocean: one of his vessels, built in the shipyard of Castellammare and carrying products from southern Italy, made a lucrative voyage to Martinique. These first attempts were followed by more frequent voyages to the Americas when strong merchant vessels were built in the Sorrento peninsula and Castellammare. However, since 1750, king Charles had been promulgating some new laws to promote the development of the Royal Navy, used particularly for the piracy defense (as in Sirago, 2004, pp. 33ss). In fact, according to Mafrici (1995). southern Italy had been in constant "state of war" during the $16^{\text {th }}$ and the $17^{\text {th }}$ centuries, when Turkish pirates and Barbary corsairs attacked its coasts and engaged in hostilities against the Spanish monarchy Therefore, Austrian Emperor Charles VI, who became king of Naples in1707, gave precise orders for the construction of vessels to defend merchant ships carrying foodstuffs for the annonary supply of the Capital from the Abruzzi and Apulia. Furthermore, the Emperor decided to engage in negotiations with the Ottoman Gate in order to trade securely in the Mediterranean, as in Sirago (2016). According to Di Vittorio (1979), some trade agreements were signed with the Ottoman Porte (27/7/1718), and the Barbary States (Tunis - 25/9/1725 and Tripoli - 30/4/1726 (36ss.). In accordance with Austrian government, not only did king Charles rearrange the fleet, but he also tried to lay the foundations for a lasting relationship of friendship and commerce with the Ottoman Empire and with the regencies of Tripoli, Tunis and Algiers, under Ottoman influence. Formal trade negotiations began, but it took a long time before a trade agreement following the Austrian pattern was produced. The king invited two important representatives to his court: Haci Hüseyin Efendi, special envoy of the Ottoman Sultan Mahmud, in 1741, and Mustafa Bey of Derna, envoy of Ahmed Karamanli of Tripoli, in 1743. They brought expensive gifts and came back to their countries with a trade agreement signed and sealed, which could grant the new kingdom the development of trade in the Mediterranean. According to D'Amora (2003) and Musella Guida, (2014), the first trade agreements were signed with the Ottoman Porte (April 7th, 1740) and the Regency of Tripoli (June 3rd,1741), to trade in the Mediterranean ports of call whose access had been denied so far, because of the pirate attacks supported by those same countries ( $715 \mathrm{ss}$ and $9 \mathrm{ss}$.). Further agreements were then made for the Baltic trade with the Kingdom of Sweden (June 30th,1742), with the Kingdom of Denmark (April 6th, 1748), and with Netherlands (August 27th, 1753). According to Sirago (2012a), the interest in the North Sea and the Baltic area, shown by king Charles of Bourbon from the beginning, derived from the need from raw materials only available in northern Europe, particularly wood for masts and iron for guns, both used to built the new Royal Navy, specially the vessels with 50 - 60 and 74 guns, necessary to protect the kingdom from Turkish and Barbary corsairs 'galleys (84 $85)$.

\section{Ferdinand of Bourbon (1759 -1806)}

When Charles of Bourbon became king of Spain, he resigned the crown of Naples, leaving his minister Bernardo Tanucci to head the regency council of his son Ferdinand until he attained his majority. According to Sirago (2012a), during the "Regency" of Tanucci a great number of mainmasts from the Baltic sea kept on arriving in the kingdom, carried by Dutch ships. Since 1767, they had been directly bought by Giacinto Catanti, Tanucci's brother-in-law, who had been appointed Neapolitan consul, first in Netherlands (The Hague) and then in Denmark (Copenhagen, 1766): in those years he had gained great experience in trading this kind of products, especially during his stay in Holland. In the same period, a lot of guns had been ordered in Sweden, where iron and steel industries had been flourishing since the second half of the eighteenth century thanks to English, Flemish and German workers: masts "of the North" were also imported from Sweden. Then, he decided to build some coastal fortifications with a battery of 174 guns. He ordered to import all the guns from Sweden between 1772 and 1774. In 1775, some "Masts of the North" and anchors were sent to the kingdom to be used for the new 60-gun vessels on the stocks (85ss.). However, according to Lo Sardo (1986), since the beginning of king Ferdinand's reign, his ministers had been trying to promote a close foreign policy and the economic growth through the expansion of trade - with England, for its handcrafts and salted fish (338ss.), with the Baltic sea and the Americas. The growth of the merchant navy was promoted too: in 1770, the Nautical Schools in Piano and Meta (with their ancient merchant shipyard and a long tradition of sea trade) and the Nautical school for pilots and sailors in Naples, in Giuseppe a Chiaia, were founded, as in Sirago (1999). A further improvement of the Royal fleet was carried out starting from 1779, when queen Maria Carolina appointed John Acton Commander of the Neapolitan Royal Navy. In 1783, he decided to build a new royal shipyard in Castellammare di Stabia, where big vessels with 74 guns were assembled following French plans and with the collaboration of a French engineer called Imbert. Acton's main task was centered on the organization of the Royal fleet and on the nautical education of skilled experts, both in Royal fleet and in merchant navy. However, since the Neapolitan shipyard has been built for galleys at the end of the sixteenth century, it was only suitable for the building of small boats. According to Acton, the 15 new vessels built in Castellammare had to be equipped in Naples with guns, which were ordered in Sweden in 1780 while the shipyard of Castellammare was being finished. 
As for the Royal Arms industry built in Torre Annunziata, the balls for the guns, and the plates of "iron from Muscovy" and Sweden used in industrial processes, came all from northern Europe and the Baltic sea, as in Sirago (2012a, 87ss.). Issues related to trade agreements were discussed with Ferdinando Galiani, who had been living in France for many years serving as secretary to the Neapolitan ambassador, before he was appointed Counselor at the Commercial Court. Galiani was the greatest economist of the kingdom of Naples, as in Diaz (1968, 854ss). He had worked out a definite trade agreement in 1787 between the Bourbon Kingdom and Russia to increase commerce in the Black Sea and the Baltic Sea. Actually, he had also tried to promote foreign trade with France, but he was never able to sign a trade agreement with it, as in Sirago (2012b, 203ss.). Meanwhile, trade opportunities in the Atlantic sea were opening up for king Ferdinand, particularly with the United States, as in Castellano $(1956,23 \mathrm{ss}$.) and Giura $(1967,24 \mathrm{ss}$.). According to Lo Sardo (1986), when the United States declared independence from Great Britain in 1776 (ratified by the Paris treaty, 1783), the Kingdoms of Naples and Sicily were independent and sovereign states. So, first diplomatic relations were established between the Bourbon kingdom of the Two Sicilies and the United States (338ss.). In 1783, a Neapolitan expedition sailed to the Americas (port of Saint Thomas, Virgin Islands) carrying wine, "macaroni" and other foods: it was a "polacca" called La Madonna delle Grazie e Anime del Purgatorio, commanded by Neapolitan pilots Antonio Cesali and Tomaso de Martino ${ }^{4}$. In the same year, Vincenzo Cotini, a Neapolitan merchant, asked to be appointed consul in the United States because he had learnt about a plan for a trade agreement with that country. However, the answer he received was that the king was not going to sign any agreement ${ }^{5}$, which was confirmed by Galiani a year later $^{6}$. In 1784, American representatives in Paris John Adams, Benjamin Franklin and Thomas Jefferson, three of the Founding Fathers of the American Constitution, sent the court of Naples, through Neapolitan representative in France, Luigi Pio, a draft proposal for a treaty of friendship and trade between the two countries, with special regard to the role of the free port of Messina, as in Castellano (1956, 34ss.) and Cortese (1971, 8ss.). According to Mafrici (2007), the newborn nation was particularly interested in establishing relations with the Neapolitan kingdom, because it was the only chance for the United States to trade in the Mediterranean Sea with the support of Neapolitan vessels contrasting the menace of the Barbary pirates. The plan had been put forth by Franklin, and supported by Adams and Jefferson, who were in Paris in those years for the ratification of the Declaration of Independence. One year after the ratification, the United States established diplomatic relations with the kingdom of Naples through the good offices of Franklin, who knew Gaetano Filangieri quite well: actually, they used to exchange letters and books, among them the volume Scienza della Legislazione, that Filangieri was going to publish in those same years, as in Lo Sardo (1999) and D'Agostini (2011). However, Ferdinando Galiani strongly opposed to trade agreements with the United States because he thought it was unprofitable to trade with the newborn state. According to Galiani, the United States only wanted to get international recognition, and be protected in the Mediterranean by Neapolitan navy against Barbary attacks .

A month before expressing his ideas about trading with the United States, Galiani had conducted an analysis of trade with the America since the previous three years, specifically with the Antilles: the entrepreneurs of the five or six expeditions had lost from $15 \%$ to $40 \%$ of the invested capital. According to Galiani, these results confirmed that trading with the United States, located farther than the Antilles, would have been even more unprofitable. However, it was established that sending products from southern Italy to the United States should be postponed until the arrival of the goods from northern America, particularly tobacco ${ }^{8}$. Actually, the United States were particularly interested in trading with Sicily because the port of Messina was declared a free port by decree on February $10^{\text {th }} 1783$, as in Castellano (1959, 209ss.) and D'Angelo (2010, 651ss.). In one of his letters to the minister José Moñino, count of Floridablanca, Galiani made a detailed list of goods which could have been imported from the United States and Latin America (cinnamon, coffee, cocoa, iron and nails, indigo from Carolina, turpentine, pitch, mainmasts for vessels) and a list of exportable goods produced in the kingdom (above all olive oil, citrus fruits, raisin, wine, acquavite and sulphur from Sicily). Finally, he remarked that anyway it was not a profitable trading, also because the United States were still an unreliable country in which to do business ${ }^{9}$.Unlike Galiani, Gaetano Filangieri, in his letters to Franklin, always showed genuine interest for the newborn State, where he would have liked to move. According to Lo Sardo (1999), he sent every book he wrote about legislation to Franklin, who took inspiration from him and Cesare Beccaria to write the American constitution.

\footnotetext{
${ }^{4}$ State Archive of Naples, Foreign Ministry (Archivio di Stato di Napoli, Ministero degli Esteri, then ASN, ME, 1356 I, 3/2/1783.

${ }^{5}$ ASN. ME, 4210, 12/3/1783.

${ }^{6}$ Biblioteca di Storia Patria, Napoli (then BSSPN), ms. XXX D 3, ff. 1-6, Galiani Ferdinando, Parere sullo stabilimento di rapporti commerciali e d'Amicizia con gli Stati Uniti, Napoli, 6/11/1784.

${ }^{7}$ BSSPN, ms. XXX D 3, ff. 1-6, Galiani Ferdinando, Parere.

${ }^{8}$ ASN, ME, 4210/15, 24/10/1784.

${ }^{9}$ ASN, ME, 4210, 1/7/1785.

48
} 
As a matter of fact, Filangieri hoped the negotiations with the United States would be successfully concluded, despite Galiani's disapproval: he probably wished to be appointed American consul, as in Ruggiero (2016, 99ss.). His dream was never fulfilled, even though he kept in touch with Franklin all his life. According to Lo Sardo (1999), on October 14th 1787, the American statesman sent Filangieri his last letter about the latest development of American political situation; Filangieri received it on September $27^{\text {th }} 1788$, a few days before he died, therefore it was his wife Charlotte who wrote back to Franklin (298). Finally, after signing the treaty of friendship, limits and navigation between Spain and United States (1795), as in Della Vecchia, $(1996,35)$, on May $20^{\text {th }}, 1796$, diplomatic relations were established also with the Kingdom of Naples by the appointment of John S. M. Mattiew as consul of the United States at the city of Naples (according to Della Vecchia, 1996, 35). In the same period there were three other consuls in the Italian peninsula - Leghorn (1793), as in Di Giacomo (2004c, 2004b and 2010), Rome (1797), as in Battaglia (2007) and Genoa (1799), as in Marraro (1951, I, 16), Battaglia (1998) - because the U.S. needed some strategic trading centers to expand their developing trade, particularly in the port of Livorno according to Di Giacomo (2004b, 265ss.). Later, Joseph Barnes, an American citizen, was appointed consul of the United States for the Kingdom of the Two Sicilies on February $10^{\text {th }} 1802$. Frederick Degan was assigned to Naples as consul on March 20, 1805, and Abraham Gibbs and John Broadbent were respectively appointed by President Jefferson as consuls at the Sicilian cities of Palermo and Messina, and confirmed in 1806, according to Marraro (1951, I, 18) and Lo Sardo (1986, 352ss.).

The appointment of consular officers was related to the growing American interest in Mediterranean trade. In 1797, Neapolitan consul Giovanni Mattieu asked the Supremo Consiglio delle Finanze (Ministry of Economy and Finance) to export a large amount of goods produced in the kingdom to the United States (acquavite, liqueurs, wine, refined silk, dried figs, manna, etc. $)^{10}$.Later, after the revolution of 1799 and the Parthenopean Republic, on April $4^{\text {th }} 1801$, Barnes was reconfirmed in office by Acton, and called in to deal with the imminent arrival of American ships: some of them were carrying timber, two were carrying goods to Malta ${ }^{11}$.A year later, in Sicilia Abraham Gibbs was appointed consul of Palermo and John Broadbent consul of Messina and Siracusa, as in Di Giacomo (2004a, 267), one of the most successful entrepreneurs in Palermo, as in D'Angelo (1995).Surprisingly, Gallipoli did not have any consul, although many vessels, some of which were American, sailed from Gallipoli carrying olive oil ${ }^{12}$. Finally, in 1804, Federico Degen was appointed American consul in Naples, and merchant Gennaro Montuoro from Gallipoli got the longawaited appointment ${ }^{13}$. Actually, American merchant fleet soon increased its presence in the area (from 202.000 tons in 1789 to 939.408 tons in 1800), as in Keiler (1913). According to Sirago (2004), a large number of brigs and scooners landing at the ports of Naples and Sicily usually exported many English goods, and only some colonial goods such as sugar, coffee and tobacco. The king also supported the construction of new merchant ships, like brigs, particularly those "a coffa", referring to their platforms which had to support the upper masts, whose construction was on a particular shore leave. In a short time, the merchant navy increased shipbuilding, particularly brigs and brigs ' $a$ palo' in the shipyards of Naples, Piano, Meta, Castellammare, the island of Procida, and in Sicily. According to Michela D'Angelo (2010, 658ss.), thirty-six American vessels arrived in the port of Messina between 1801 and 1804. However, when Naples was invaded by the French in 1806, the king sailed to Palermo, where he appointed Abraham Gibbs consul of the United States ${ }^{14}$.

Some trade statistics can be found in the text of Pitkin, but he generically cites Italy. However, from these data we can have an idea of trade with the United States, which was developing in the early 1800s. Infact between 1800 and 1806, trade with the United States had a certain increase. The trade of the United States with Italy has consisted principally in carrying dried or smoked fish, sugar, coffee and cocoa and in bringing from silks, wines, brandies, fruit, some lead and cheese. The tables show the exports in Italy of fish, sugar and coffee between 1800 and 1806.

Table 1. Exports of fish dried or smoked (in quintals)

\begin{tabular}{|c|c|c|c|c|c|c|}
\hline 1800 & 1801 & 1802 & 1803 & 1804 & 1805 & 1806 \\
\hline 24.492 & 27.866 & 11.239 & 2.694 & 0,417 & 13.272 & 18.458 \\
\hline
\end{tabular}

\footnotetext{
${ }^{10}$ ASN, ME, 3196, 13/4/1797.

${ }^{11}$ ASN, ME, 3196, 4/4, 18/4, 25/5/180.1

12 ASN, ME, 3196, 27/2/1801, Gallipoli; 7/2/1803, Consul Salvatore Corti for Messina and Siracusa.

13 ASN, ME, 3196, 26/5 and 26/9/1804.

${ }^{14}$ ASN, ME, 3196.
} 
Table 2. Exports of withe sugar (in libras)

\begin{tabular}{|c|c|c|c|c|}
\hline 1803 & 1804 & 1805 & 1806 & 1807 \\
\hline 872.999 & 2.571 .341 & 3.357 .346 & 8.060 .191 & 9.476 .602 \\
\hline
\end{tabular}

Table 3. Exports of coffee (in pounds)

\begin{tabular}{|c|c|c|c|c|c|c|}
\hline 1800 & 1801 & 1802 & 1803 & 1804 & 1805 & 1806 \\
\hline 2.094 .642 & 1.288 .125 & 3.286 .825 & 1.405 .150 & 1.439779 & 1.759 .206 & 4.948 .814 \\
\hline
\end{tabular}

Table 4. Exports and Imports - Value from 1795 to 1801 (in dollars)

\begin{tabular}{|r|r|r|}
\hline Year & \multicolumn{1}{|c|}{ Exports } & \multicolumn{1}{c|}{ Imports } \\
\hline 1795 & 1.223 .150 & 319.653 \\
\hline 1796 & 1.100 .522 & 268.237 \\
\hline 1797 & 767.664 & 652.408 \\
\hline 1798 & 1.334 .036 & 724.209 \\
\hline 1799 & 1.157 .212 & 753.484 \\
\hline 1800 & 2.689 .968 & 1.104 .833 \\
\hline 1801 & 2.090 .439 & 902.406 \\
\hline
\end{tabular}

\section{The French Decade 1806 - 1816}

After Napoleon's rise to power, the Italian peninsula was occupied by the French in 1806. The Bourbons fled to the island of Sicily, in Palermo, under British protection. Trade increased very much in Messina during the so called "British decade" (1806-1816): between 1810 and 1811, nineteen American vessels arrived in the port of the city (according to D'Angelo (2010, 656).

The Napoleonic age brought remarkable changes in the Kingdom of Naples, which was ruled first by Napoleon's brother Joseph, and then by Napoleon's brother-in-law Joachim Murat. Murat decided to expand the arsenal of Castellammare and ordered to build three docks to make three vessels simultaneously (following a plan that was carried out later, in the 1820s, under the Bourbon rule, as in Sirago (2012a). However, the recession caused by the English Continental Blockade (signed on November $21^{\text {st }}$, 1806) hindered trade with the Baltic Sea, the Black Sea, and the Americas.

On September $20^{\text {th }} 1808$, President James Madison appointed Alexander Hammett from Maryland consul in Naples: his task was to check the American vessels entering the port of the city with their expensive goods (specially coffee, sugar, cocoa, cod fish) who arrived on September $25^{\text {th }}$ on a ship from Baltimore and asked for licenses for the transport of goods ${ }^{15}$. But the controversy with the United States arose in 1809 when Murat, with Napoleon's approval, decreed that American ships that ventured out into the bay of Naples could be seized and confiscated. The first case was the brig Nancy, captain Wilston Banston, captured on September 1808 by the Neapolitan fleet near the islands of Procida and Ischia, while sailing to Gallipoli to load olive oil ${ }^{16}$, according to Ilari Crociani Boeri $(2016,211)$. In March the schooner Kate captain Thompson arrived from Naples to Baltimore for Naples with loads of coffee and timber and was stopped outside the port of Naples by gunboats that escorted him to Nisida for quarantine ${ }^{17}$.Also the schooner Mary Beverley, by Massachusetts, captain Henry Locorn, with sugar, pepper, fish cod, cotton, tobacco, directed in Sardinia, in June 1089 was seized in the port of Naples where he was headed for the winds contrary. And the goods of the ships were immediately sold ${ }^{18}$. Then the Neapolitan shopkeeper Giuseppe Mongiardino asked to buy the goods (sugar and coffee) of two other ships seized, the schooner Zephyrus, Captain Murley and the brigantine The Sofia Captain Samuel Carmen ${ }^{19}$. Also, the shopkeepers of Legorn Antonio and Giuseppe Fili claimed compensation for goods seized from Captain Brown (Java coffee and sugar from Havana), sold after the seizure of the ship. And the same happened for the goods carried on the ship Hercules captain Edward West who came from Salerno with colonial genres (sugar, tea). Of course, the consul Degan expressed his disappointment at these events that were slowly destroying trade with the United States, a trade that in the past years had shown some development ${ }^{20}$.

${ }^{15}$ ASN, ME, 5384/2, September $20^{\text {th }} 1808$ and 8 , September $25^{\text {th }} 1808$.

${ }^{16}$ ASN, ME, 5383/1, 2179/1808, Letter of the United States' Consul Degan.

${ }^{17}$ ASN, ME, 5383/1, 2/3/1809, Letter of Consul Degan.

${ }^{18}$ ASN, ME 5383/2, 9/6 and 20/7/1809, Supplication of the captain and letter of Degan to marquise of Gallo, Neapolitan Minister of Foreign Affairs.

${ }^{19}$ ASN, ME, 5383, June 1809.

${ }^{20}$ ASN, ME, 5383, 1809.

50 
But the seizures continued: on September $14^{\text {th }}, 1809$ was seized the ship Augusta captain Maone of Baltimore coming from Tunis with cocoa and coffee; and on September $30^{\text {th }}$ the brig Sophia captain Carman of Baltimora with coffee, sugar and woods and the brig Romp captain Lanter of Salem, with coffee, cocoa, pepper, sugar, wood, cod fish, indigo $^{21}$. In 1809 thirty-nine vessels were seized) ${ }^{22}$. And it is estimated that between 1809 and 1812 about fifty vessels were captured and sold with their cargoes or added to the Royal fleet ${ }^{23}$.

Table 5. Ships seized in the harbor of Naples in $1809(28 / 5-5 / 8)^{24}$

\begin{tabular}{|c|c|c|c|c|c|c|}
\hline Ship & Captain & Ton. & Crew & By & To & GOODS \\
\hline Schooner Schalore & G. Mattew & 175 & 7 & Philadelphia & Cagliari & Sugar coffee \\
\hline Brig Caroline & G. Drow & 185 & 9 & Boston & Messina & Rum hemp pitch \\
\hline Ship Hercules & E. Weit & 285 & 17 & Salem & Naples & Sugar cod fish \\
\hline Brig Zombo & R. Holden & 144 & 7 & Baltimora & Palermo & Sugar coffee \\
\hline Ship Margaret & W. Farcelch & 275 & 12 & Nisida & Tunis & Empty \\
\hline Brig Froobetis & J. H. Gardeners & 141 & 8 & Beverley & "to the fortune" & \\
\hline Brig Scomps & G. Lande & 232 & 13 & Salem & Naples & Sugar coffee \\
\hline Schooner Kele & A.Thompson & 420 & 15 & Baltimore & Naples & Sugar etc. \\
\hline Brig Victory & J. Tell & 176 & 8 & Salem & Naples & Pepper sugar \\
\hline Ship Trent & J. Cuvandish & 191 & 12 & Salem & Naples & Sugar coffee \\
\hline Schooner Omotonach & W. Schiffield & 130 & 8 & Boston & Naples & Cod fish tobacco \\
\hline Schooner Syren & J. Jauswin & 107 & 7 & Newbury & Sicily & Cod fish \\
\hline Brig The Phoenix & S, Uskell & 108 & 10 & Algiers & Naples & Empty \\
\hline Schooner Peace & W.Graves & 91 & 7 & Newbury & Sicily & Cod fish \\
\hline Brig Emily & D. Watermann & 199 & 14 & New York & Naples & Sugar indigo \\
\hline Ship Francis & W. Aschel & 267 & 49 & Salem & Naples & Pepper \\
\hline Schooner Hound & N. Waren & 144 & 14 & Baltimore & Naples & Sugar coffee \\
\hline Schooner Dove & D. Thoms & 67 & 5 & Beverley & Naples & Cod fish \\
\hline Schooner Martha & R. Seuland & 154 & 11 & Boston & Naples & Sugar wax \\
\hline Schooner Urania & J. Mc Pex & 77 & 13 & New York & Naples & Coffee \\
\hline Schooner Amherit & C. Breadford & 89 & 6 & Plumrel & Naples & Cod fish \\
\hline Brig Rose Mary & W. Candner & 137 & 8 & Philadelphia & Naples & Coffee \\
\hline Schooner Luck & S. Morten & 112 & 8 & Boston & Naples & Tobacco cotton \\
\hline Schooner William & M. Torwey & 79 & 6 & New York & Naples & Sugar pepper \\
\hline Schooner Nancy & G. Hollen & 49 & 6 & Salem & Naples & Sugar cod fish \\
\hline Brig Nancy Haun & M. Brun & 173 & 8 & Boston & Naples & Cod fish \\
\hline Schooner Mary & J. Derby & 80 & 7 & Salem & Naples & Sugar cod fish \\
\hline Schooner Lousiana & T. Newhall & 82 & 7 & Boston & Naples & Cocoa \\
\hline Brig Johan & E. Corrier & 117 & 7 & Newburg & Naples & Fish cod \\
\hline Schooner Johan & P. Diney & 65 & 5 & Tanger Alicante & Naples & Sugar coffee \\
\hline Brig Betsy & A. Sluker & 154 & 7 & Salem & Naples & Coffee cocoa \\
\hline Schooner Hamilton & W. Brown & 120 & 12 & Tunis & Naples & empty \\
\hline Ship Wretress & J. Horbell & 220 & 11 & Tunis & Naples & empty \\
\hline Ship Henery & G. Gardener & 190 & 11 & Boston & Naples & Sugar coffee \\
\hline Brig Alexander & W. Piket & 131 & 8 & New Port & Naples & Sugar coffee \\
\hline Schooner Ocean & W.Wilson & 74 & 8 & Boston & Naples & Coffee cod fish \\
\hline Schooner Dolphin & Finc & -- & 8 & Tunis & Naples & empty \\
\hline Brig The Victory & P.Pulch & 176 & 9 & Boston & Naples & empty \\
\hline Schooner Auctonak & L. Lee & 137 & 7 & Wordhown in Sweden & Naples & Leather \\
\hline
\end{tabular}

${ }^{21}$ Ibidem.

${ }^{22}$ ASN, ME, 4466, Naples, 20/1/1810.

${ }^{23}$ ASN, ME, 4466, Note of the 30 seized vessels in 1809.

${ }^{24}$ ASN, ME, 4466, Naples, 20/1/1810. 
Meanwhile in 1810 the consul Degan was working to return the crews of ships seized in America by requesting the Neapolitan government 32,000 ducats obtained from seized loads to which were added another 14800 ducats for other expenses and for their maintenance (for a total of 48,000 ducats) ${ }^{25}$, requests and complaints renewed in $1811^{26}$. However, the same year was seized the schooner Ocean captain Wilhelm Wilson with many goods (sugar, indigo of Louisiana, etc.) and the new consul Alexander Hammett claimed again because the captain and the crew had been arrested and locked up in the Vicaria prison ${ }^{27}$. In 1812 other ships were seized: the schooner Betsey of Marblehead, captain William B. Orte, the brig Harc, captain Charles Bestody, the ship Golden Age with herrings; the confiscated goods were sold despite the protest of the merchants who had rented the ships for the transport of the products they purchased $^{28}$. Also, the schooner Mary of Boston, captain John Drew, thrown by the currents on the coasts of Calabria, carrying money, was seized ${ }^{29}$. And the same happened to the ships Pocahontas, captain David Smith Junior of New York, and to the ship Concord Admittance of Boston, whose cargoes were seized and sold ${ }^{30}$.

In fact, the marquis of Gallo, Marzio Mastrilli, minister of foreign affairs, was worried about the trade with the United States since the sugar came from the Louisiana and Florida: so, I wanted to exclude them from the embargo. Therefore, the regent, Queen Maria Carolina, wrote to France for information how to act ${ }^{31}$. And the French government replied that the American sugar could be imported in spite of the embargo but there were also other goods in the cargo ${ }^{32}$.

Although the development of trade was hindered by the war between France and England, American merchant navy collaborated with the English trading companies working in Naples, and the fleet was allowed to enter the port of the city, as in Lo Sardo (1986, 376).

The embargo was effective intermittently for about half the time and it ended on $11^{\text {th }}$ April 1814 , after Napoleon's first abdication. In 1813, when the Continental blockade and, consequently, trade restrictions ended, consul Hammett renewed his claims to the Marquis del Gallo, Minister of foreign affairs, for the loss suffered after American vessels were seized and sold in with their cargoes, among which there was the ship Victory with a cargo containing cocoa and belonging to the consul himself, whose value amounted to 6.000 ducats $^{33}$. However, claims were never satisfied also because it was the end of Napoleonic era, as in Radogna (1978, 70ss.) and Lo Sardo (1986, 390ss.).

The trade naturally resented the upheaval caused by the Napoleonic wars, drastically decreasing, especially after the seizure of American ships in Naples, and this began a slow recovery only after 1816.

Table 6. Exports of fish dried or smoked (in quintals)

\begin{tabular}{|c|c|c|c|c|c|c|c|}
\hline 1807 & 1808 & 1809 & 1810 & 1811 & 1812 & 1815 & 1816 \\
\hline 13.837 & 6.463 & 3.103 & 11.501 & 12.005 & 30.003 & 15 & 10.519 \\
\hline
\end{tabular}

Table 7. Exports of brown sugar (in libras)

\begin{tabular}{|c|c|c|c|c|c|}
\hline 1808 & 1809 & 1810 & 1811 & 1812 & 1816 \\
\hline 2.636 .906 & 2.128 .124 & 859.120 & 62.494 & 8.454 & 4.704 \\
\hline
\end{tabular}

Table 8. Exports of coffee (in pounds)

\begin{tabular}{|c|c|c|c|c|c|c|c|}
\hline 1807 & 1808 & 1809 & 1810 & 1811 & 1812 & 1815 & 1816 \\
\hline 3.490 .495 & 1.133 .643 & 986.074 & 784.423 & 188.207 & 1.100 & 754.843 & 1.111 .013 \\
\hline
\end{tabular}

\section{Conclusion}

The kingdom of the two Sicilies was particularly interested in restoring diplomatic relations with the United States, which had been damaged by Murat's illegal seizure and confiscation of the American ships, and the consequent indemnity requests of those American merchants who had suffered economic loss.

\footnotetext{
${ }^{25}$ ASN, ME, 5383, 21/3/1810, Letter of consul Degan.

${ }^{26}$ ASN, ME, 5383/4, 10/1/1811.

${ }^{27}$ ASN, ME, 5383/4, 10/11/1811 and 3/5/1815.

${ }^{28}$ ASN, ME, 5383/5, 12 -14 March - 30 April 1812.

${ }^{29}$ ASN, ME, 5383/5, 30 April, 8 May 1812.

${ }^{30}$ ASN, ME, 5383/5, 6 May 1812.

${ }^{31}$ ASN, ME, 5383/5, 10 July - 6 August 1812.

${ }^{32}$ ASN, ME, 5383/5, 27 August 1812.

${ }^{33}$ ASN, ME, 5458/7, 1813 e 13 May1814.

52
} 
On February $28^{\text {th }}, 1816$, President James Madison appointed William Pinkney, the famous statesman and diplomat, Minister Plenipotentiary to Russia "with a special mission to the King of the Two Sicilies" to make indemnity requests for the illegal seizure of the American vessels, following the instructions he was given on May $11^{\text {th }}, 1816$. On July $23^{\text {rd }}$, Pinkney arrived in Naples on a ship called Washington, escorted by the American navy ${ }^{34}$ : one month later, he went to the king's court with Frederick Degan, consul of the United States, to discuss "the principal objects of his mission"35. Pinkney's task was to urge king Ferdinand to return the ships with their cargoes. Unfortunately, the King was reluctant to give anything Murat had seized back: actually, he considered him a usurper, as reported by the Marquis of Circello, Tommaso di Somma, Minister of Foreign Affairs ${ }^{36}$, as in Marraro (1948). Although Pinkney had failed, diplomatic relations were re-established, and trade with the Americans increased, especially in Sicily, as in Di Giacomo (2004a) ${ }^{37}$.

However, the negotiations between the kingdom and the U.S. started again only after the death of king Ferdinand (26/1/1825), when his son Francis I succeeded to the throne. On April $10^{\text {th }} 1825$, count Ferdinando Lucchesi Palli was appointed consul general in the United States "per sempre più promuovere la Navigazione della Reale Bandiera e il Commercio" (to promote navigation and trade in the kingdom). On September $16^{\text {th }} 1825$, Luigi de Medici di Ottaviano, minister of foreign affairs, wrote a long report about the open question of the illegal seizure of the American vessels, Pinkney's unsuccessful mission, and the indemnity claims presented on August $18^{\text {th }}$ by John James Appleton ${ }^{38}$, special agent of the U.S. at Naples: the minister urged to settle the controversy following the principles of the trade agreement between France and the U.S. signed on June $24^{\text {th }} 1822^{39}$. Later, in 1826, while talks over seized US ships and cargoes were still underway in Naples, and many merchants were sending reports claiming for damages, Edward Everett (1826) published a remark called «Claims of Citizens of the United States of America» complaining against Naples, Holland and France" for the spoliations committed on U.S. commerce during the Napoleonic wars. In addition, consul Lucchesi Palli reported that some American citizens had formed a partnership for the purpose of requiring indemnity and satisfaction for those claims ${ }^{40}$. The controversy did not stop the development of trade between the two countries. Actually, consul Odoardo Fowles, replacing Lucchesi Palli (who got sick and went back to Italy) ${ }^{41}$, in 1827 announced the arrival, in the port of New York, of two American brigs - Washington and The United States - carrying goods from the kingdom of the two Sicilies, including some wine, olive oil, citrus fruits, fresh fruit and silk ${ }^{42}$. Only one year later, in 1828, the brig called Felicità, commanded by captain Vincenzo Lorello, had sailed from New York to Palermo carrying different types of goods (pitch, sugar, timber, tobacco, etc. ${ }^{43}$. As a matter of fact, trade gradually developed, even though the controversy with the U.S. had not been settled yet. The situation radically changed when Ferdinand II succeeded to his father Francis I (died on November $8^{\text {th }}$ 1830). The new king started to restore the finances of the kingdom, supported technological improvement, promoted the reorganization of the Military navy as well as of the Merchant Navy, and, finally, increased trade with foreign countries, according to Sirago (2004).Then, small entrepreneurs and shipbuilders joined together to build a great number of ocean-going brigs, because they strongly wanted to trade with the U.S., as Carlo Afan de Rivera remarked (1833, I, 39 - 40), which encouraged the development of the merchant navy, according to Clemente (2011, 213 ss,). This new atmosphere encouraged the resolution of the “American question”. In 1831 President Jackson sent John Nelson, from Maryland, to Naples with explicit orders to settle the dispute, according to Marraro (1951, I, 20). A definitive agreement was reached in October 1832, when Nelson returned to the United States with the text of the first convention between the United States and the Kingdom of the Two Sicilies, according to Marraro (1951, I, 21). The content of the agreement had been previously discussed on February $29^{\text {th }}$, when the king had suggested a trade treaty with the United States ${ }^{44}$. Finally, it was signed on October, $14^{\text {th }}$, when all the clauses were accepted. The king had to pay 2.155.000 Neapolitan ducats including indemnity for the destruction of vessels and cargoes.

\footnotetext{
${ }^{34}$ ASN, ME, 4, 23/7/1816.

${ }^{35}$ ASN, ME, 4465, 24/8/1816.

${ }^{36}$ ASN, ME, 4465, 28/8/1816.

${ }^{37}$ ASN, ME, 2408, 25/9/1818.

${ }^{38}$ ASN, ME, 4465, 18/8 and 16/9/1825.

${ }^{39}$ ASN, ME, 4465.

${ }^{40}$ ASN, ME, 4465, 28/7/1826.

${ }^{41}$ ASN, ME, 2406, 24/7/1827.

${ }^{42}$ ASN, Me, 2409, 1826, 8- 9 August.

${ }^{43}$ ASN, ME, 2410, 8/6/1828.

${ }^{44}$ ASN, ME, 4466,29/2/1832.
} 
In addition, the sum of 7.685 ducats, subtracted from the total amount, was used to reimburse the United States Government for the costs of taking American seamen back from Naples in 1810. The sum was paid in nine instalments of 235.000 ducats at $4 \%$ interest until $1842^{4546}$. The satisfactory conclusion of the indemnity claims led American Government officials to believe that the time was ripe to negotiate a treaty of general commerce between the two countries.

Historical evidence suggests that after the settlement of the controversy between the United States and the Kingdom of the two Sicilies, caused by Murat's illegal seizure and confiscation of the American ships, the two countries increased their bilateral trade. Although Count Ferdinando Lucchesi Palli had been appointed consul in Washington in 1826, formal diplomatic relations were established after the trade agreement was signed in 1832. John Nelson presented his credentials to the King of the Two Sicilies on January 25, 1832, while the first U.S. Minister Resident in Naples was Robert Dale Owen, who presented his credentials on September 20, 1854 before the convention was ratified. The kingdom of the two Sicilies also appointed its own ambassadors: Chevalier Rocco Martuscelli presented his credentials as Chargé affairs at Washington on December 7, 1846. Since then, the Government of the Two Sicilies has been almost continuously represented in the United States by a Chargé affairs until 1861. The last of them was Giuseppe Anfora (duke of Licignano), who acted as Chargé affairs ad interim from September 24, 1860, to December 15, 1861, as in Marraro, (1952, II, tables 747ss.).

\section{References}

Amicolo, R. (2013). Gaetano Filangieri e Benjamin Franklin le implicazioni politiche di una amicizia filosofica. L'Incoacervo, 14 - 27.

Ascione I., (1996). Immagini dell'America nei documenti diplomatici napoletani, in Spikes D. editor, Stati Uniti a Napoli: rapporti consolari 1796 - 1996, Napoli, Filema, 75 - 128.

Battaglia R. (1998). Stelle e strisce sotto la Lanterna. Il commercio tra gli Stati Uniti e Genova dalla seconda presidenza Madison alla Guerra civile, Messina, EDAS.

Battaglia R. (2007). Consular and Commercial Relations between the United States and the Italian States in 1800 1861, in Vassallo C. and D'Angelo M. editors, Anglo - Saxons in the Mediterraneean. Commerce, Politics and Ideas (XVII-XX Centuries), $151-166$.

Castellano, G. (1956). Riforme borboniche (II), Relazioni internazionali e politica commerciale estera del Regno delle Due Sicilie nel secolo XVIII con particolare riguardo agli Stati Uniti d'America, Archivi. Archivi d'Italia e rassegna internazionale degli archivi, s. II, XXIII, fs. I, 22-48 and fs. 2-3, $177-210$.

D’Agostini, M. (2001). Gaetano Filangieri and Benjamin Franklin: between the Italian Enlightenment and the U.S. Constitution, research conceived and directed by the lawyer Giannicola Sinisi and carried out by the Italian Embassy in Washington, in collaboration with the American Philosophical Society of Philadelphia, the Library of Congress and the Civic Museum Gaetano Filangieri in Naples, Washinghton, March $17^{\text {th }}$ www.academia.edu.

D'Amora, R. (2003). The diplomatic, relations between Naples and the ottoman empire in the mid - eighteenth century: cultural perceptions, Oriente Moderno, n.s. 22 (83), n.3, The ottoman Capitulations: text and context, $715-727$.

D'Angelo, M. (2010). The Emporium of Trade of the Two Seas': The re-lanching of the port of Messina 1784 - 1815 , in D’Angelo M. Harlaftis G. Vassallo C.editors, Making waves in the Mediterranean Sulle onde del Mediterraneo, Messina, Istituto di Studi Storici G. Salvemini, 651 - 667.

Della Vecchia, R. (1996). Il dibattito sull'istituzione di un consolato degli Stati Uniti a Napoli alla fine del Settecento (1783 - 1796), into Spikes D. editor, Stati Uniti a Napoli: rapporti consolari 1796 - 1996, Napoli, Filema, 23 $-37$.

Diaz, F. (1968). L'abate Galiani consigliere di commercio estero del regno di Napoli, Rivista Storica Italiana, 855 909.

Di Giacomo, S. (2004a). Rapporti tra Sicilia e Stati Uniti, Messina, Annali della Facoltà di Economia dell’Università, pp. $265-311$.

Di Giacomo S. (2004b). Toscana e Stati Uniti nella prima metà dell'800: i consoli di Livorno e il caso Ombrosi, Rassegna Storica Toscana (Olschki, Firenze), L, 1, 37 - 56.

\footnotetext{
${ }^{45}$ ASN, ME, 4466, 14/10/1832, Convenzione tra S.M. il Re delle Due Sicilie e il Governo degli Stati Uniti d'America per terminare le reclamazioni del detto Governo per le prede fatte da Murat negli anni 1809, 1810, 1811, e 1812.
} 
Di Giacomo, S. (2004c). Dall'Atlantico al Mediterraneo. I rapporti commerciali e diplomatici tra gli Stati Uniti e Livorno (1831 - 1830), Soveria Mannelli (CZ), Rubettino ed.

Di Giacomo, S. (2007), U.S. Consuls and Travellers in Nineteenth Century Sicily, into Vassallo C. and D'Angelo M. editors, Anglo - Saxons in the Mediterraneean. Commerce, Politics and Ideas (XVII - XX Centuries), 167 179

Di Giacomo, S. (2010). Trade and consular relations betweeen the United States and Livorno in the mid - 19th century, in D'Angelo M., Harlaftis G., Vassallo Carmel editors, Making waves in the Mediterranean Sulle onde del Mediterraneo, Messina, Istituto di Studi Storici G. Salvemini, 565 - 568.

Di Vittorio, A. (1979). Il commercio tra Levante Ottomano e Napoli nel secolo XVIII, Napoli, Giannini Editore.

Everett, E. (1826). Claims of citizen of the United States of America on the Governements of Naples, Holland and France, Printed by Hilliard and Metcalf, Cambridge, 1826.

Giura, V. (1967). Russia, Stati Uniti d'America e Regno di Napoli nell'età del Risorgimento, Napoli, E.S.I.

Indelli, T. (2009). Bellum piraticum e pirateria. Aspetti giuridico - politici del fenomeno piratico dall'età romana al XVIII secolo, Salerno, Editrice Gaia.

Keiler, H. (1913). American Shipping Its History and Economic Conditions, Jena, Verlag Von Gustav Fisher.

Ilari, V Crociani, P. Boeri, G. (2016). Le marine italiane di Napoleone La marina napoletana di Murat (1806 - 1805), Roma, Collana SISM (Società Italiana di Storia Militare)

Lo Sardo, E. (1986). L'espansione economica statunitense nel Mediterraneo e il Regno delle due Sicilie (1784 - 1812) ,Archivio Storico per le Province Napoletane, 335 - 398.

Lo Sardo, E. (1999). Il mondo nuovo e le virtù civili. L'epistolario di Gaetano Filangieri (1772 - 1888), Napoli, Federiciana Editrice Salernitana.

Mafrici, M. (2002). I mari del Mezzogiorno d'Italia tra cristiani e musulmani. In Barberis W. editor, Guerra e pace, Il mestiere delle armi: da cavalieri a soldati, Storia d'Italia, Annali 18, Torino, Einaudi, 73-121.

Mafrici, M. (2007). Il Mezzogiorno d'Italia e il mare: problemi difensivi nel Settecento, in Cancila R. editor, Mediterraneo in armi (sec. XV -XVIII), Mediterranea. Ricerche storiche, 4, 2 tomi, II, 637- 663, www.mediterranea.it.

Marraro, H.R. (1948, dec.). William Pinkney's mission to the Kingdom of the Two Sicilies, 1816, Maryland Historical Magazine, 235 - 265.

Marraro, H.R. (1951-52). Diplomatic relations between the United States and the Kingdom of the Two Sicilies Instructions and despatches 1816 - 1861, S. F. Vanni (Ragusa), New York, 2 voll.

Musella Guida, S. (2014), Relazioni politiche e commerciali tra il Regno di Napoli e la Porta Ottomana nei primi anni del regno di Carlo di Borbone. I doni per e da Mahmud I,in Mondi lontani, Quaderni di Palazzo Reale, Porzio A. editor, 9 - 28.

Pitkin, T. (1817), Statistical view of the commerce of the United States, New York.

Radogna, L. (1978). Storia della Marina Militare delle Due Sicilie (1734 - 1860), Milano, Mursia editore.

Ruggiero, G. (2016). Gaetano Filangieri, introduttore degli ambasciatori: le delusioni di un intellettuale, Archivio Storico per le Province Napoletane, 99 - 130.

Sirago, M. (1999). Scuole per il lavoro. La nascita degli istituti 'professionali' meridionali nel dibattito culturale tra fine '700 e inizi '800, Rassegna Storica Salemitana, 109 - 172.

Sirago, M., (2004). Le città e il mare. Economia portuale, identità culturale dei centri costieri del Mezzogiorno moderno, Napoli, Edizioni Scientifiche Italiane.

Sirago, M. (2012a). The shipbuilding industry and trade exchanges between the kingdom of the Two Sicilies and the countries of the Baltic and the Black Sea (1734 -1861), Mediterranean Review, IMS, 5, n. 2, 81 -107.

Sirago, M. (2012b). Il consolato napoletano nel Mar Nero e lo sviluppo di Odessa tra la fine del '700 e la prima metà dell'800, into Mafrici M. and Mascilli Migliorini L. editors, Mediterraneo elè Mar Nero. Due mari tra età moderna e contemporanea, Convegno internazionale, Procida 26-27/9/2008, Napoli, Edizioni Scientifiche Italiane, 203-233.

Sirago, M. (2015). The development of the new steamships and the history of the shipping industry in the Kingdom of Two Sicilies(1816-1861), in Pisano R. editor, A Bridge between Conceptual Frameworks, Sciences, Society and Technology Studies, Amsterdam, Springer, 495-511.

Sirago, M. (2016). La ricostruzione della flotta napoletana e il suo apporto alla difesa dei mari nel viceregno austriaco (1707 - 1734), Archivio Storico per le Province Napoletane, 71 - 98. 